\title{
Mock Trial Simulation in Teaching Syariah Law of Evidence at Faculty of Law, UKM: A Blend of Traditional and New Methods
}

\author{
Ahmad Azam Mohd Shariff ${ }^{1}$ \\ Ramalinggam Rajamanickam² \\ Tengku Noor Azira Tengku Zainudin ${ }^{3}$ \\ Safinaz Mohd Hussein ${ }^{4}$ \\ Nazura Abdul Manap 5 \\ Mazliza Mohamad6 \\ Asma Hakimah Ab Halim ${ }^{7}$ \\ Fatimah Yusro Hashim ${ }^{8}$ \\ ${ }^{1}$ Associate Professor, Faculty of Law, Universiti Kebangsaan Malaysia; aazam@ukm.edu.my \\ 2 Lecturer, Faculty of Law, Universiti Kebangsaan Malaysia; rama@ukm.edu.my \\ ${ }^{3}$ Associate Professor, Faculty of Law, Universiti Kebangsaan Malaysia; tna@ukm.edu.my \\ ${ }^{4}$ Associate Professor, Faculty of Law, Universiti Kebangsaan Malaysia; finas@ukm.edu.my \\ ${ }^{5}$ Associate Professor, Faculty of Law, Universiti Kebangsaan Malaysia; nazura@ukm.edu.my \\ 6 Lecturer, Faculty of Law, Universiti Kebangsaan Malaysia; mazliza@ukm.edu.my \\ ${ }^{7}$ Lecturer, Faculty of Law, Universiti Kebangsaan Malaysia; hakimah@ukm.edu.my \\ 8 Lecturer, Faculty of Law, Universiti Kebangsaan Malaysia; wardatun@ukm.edu.my
}

Doi:10.5901/mjss.2016.v7n3p144

\section{Abstract}

The Syariah Law of Evidence is one of the syariah courses in the combined civil and syariah LLB programme at the Faculty of Law, UKM. A revamp of the curriculum has seen practical mock trial been embedded in the course. The mock trial trains students on correct methods and techniques to submit evidence in civil and syariah criminal trials. This is in line with the aim of the faculty to have a practical balance between theories and practices in its legal curriculum. Mock trial simulation in teaching law of evidence is both an in- vitro and vitro practical experience extremely important to the students. It simulates practical skills of evidence submission in trials. Mock trial teaches students of crucial roles of proper evidence in syariah courts trials. This paper critically examines challenges faced in the teaching and learning of this course. All arguments and findings in this paper rests on a qualitative design, using methodologies of critical and content analysis, field interviews and observation for data verifications. It simultaneously explores possible ways of overcoming these obstacles in ensuring relevancy of the syariah course in ensuring marketability of the graduates.

Keywords: Syariah Law of Evidence, teaching and learning, mock trial simulation, curriculum

\section{Introduction}

Syariah Law of Evidence was introduced as a law subject at Faculty of Law, Universiti Kebangsaan Malaysia in 1997. At that point of time, its introduction into the legal curriculum at UKM was deemed timely as Malaysia's Parliament had just passed two new syariah legislations in forms of the Syariah Court Evidence Act and the Syariah Criminal Procedures Act (Faridah, 2014). The Faculty of Law, UKM had taken the bold step in exposing law students to the application and practical aspects on syariah law of evidence and procedures. The inception of syariah law subjects at the law faculty was a gradual one (A. Haji, 2013).

The above process of evolvement and inception becomes the focal point of this study. This research centres on the following objectives. First of all, this research aims at delving into the history of such inception whereby the evolvement of syariah subjects had led to the introduction of the subject of Syariah Law of Evidence and Procedures. In 
view of the demand by the current legal industry in the said field which has resulted in the faculty reviewing course contents of all syariah subjects, this research also examines the course content of Syariah Evidence Law as per the current industry needs. Furthermore, based on the field research conducted among law students at the faculty, the research also identifies the shortcomings in the said course content and aims to improve the content accordingly. Last but not least, this research suggests enhancement to the course content to enable it to fulfil the demands of the syariah legal industry, particularly in providing evidence during trial.

The significance of this research is clear. It points at the process of evolvement of the course of Syariah Law of Evidence, being the catalyst for production of law graduates who are aptly and adequately equipped by theoretical knowledge and practical skills. This whole process of evolvement of the syariah courses in general and the course of Syariah Evidence Law in particular at the Faculty of Law, UKM, Malaysia reflects the tireless effort put in by past and current administration of the faculty to ensure marketability of the faculty's law graduates. The academic and teaching staff of the course of Syariah Evidence Law at the faculty also displays indomitable efforts in support of this effort. This has no doubt leads to incorporation and inception of the mock trial simulation method into the course to hone the students' practical skills.

\section{The Research: Its Objectives, Literature Review and Methodologies}

As already mentioned, the whole research is built on these clear objectives. This research first and foremost aims at delving into the history of the evolvement of syariah courses in general and the course of Syariah Law of Evidence and Procedures in particular. This research also examines the course content of Syariah Evidence Law as per the current industry needs. In addition, the research also identifies the shortcomings in the said course content and aims to improve on the content accordingly. Last but not least, this research suggests enhancement to the course content to enable it to fulfil the demands of the syariah legal industry, particularly in providing evidence during trial.

The research identifies problems and findings in reliance of some first-hand literatures written by influential academicians and administrators of the Law Faculty UKM, Malaysia. Among these papers, a few are pivotal materials are used in support of this research problems and findings. First and foremost, a paper presented by A. Haji B. at a the Law Faculty's Retreat Programme at Cheringin Hill Resort, Janda Baik, Pahang in 2013 entitled Bachelor of Law Programme at Faculty of Law UKM: A curriculum Review. Next is a paper presented by A. Halim Muhammad at the Faculty of Law's Retreat Programme at Riviera Resort, Melaka in 1996 entitled Syariah Courses at the Law Faculty UKM: An Overview of Its Significance and Development. Another important paper referred to in this research is the one written by Ahmad A. Mohd Shariff in October 2013 entitled Teaching and Learning of Syariah Evidence Course: A UKM's Law School Experience, a paper presented at International Conference on Teaching and Learning, Universiti Sains Islam Malaysia (USIM), Nilai, Negeri Sembilan. Another important paper referred to in this research is the one written by A. Hakimah A. Halim in 2014 entieled Review of LL.B Curriculum at UKM's Faculty of Law: A Report on Syariah Courses Content Review. The paper was presented at a Workshop on Law Curriculum Review, Port Dickson, Negeri Sembilan on May 2014. Last but not least, it is fitting that this research refers also to a material written by Faridah A. Jalil entitled Law Curriculum Review by Faculty of Law UKM: Proposed Amendments and Revamps. Workshop on Undergraduates Teaching and Learning. The paper was presented at a workshop at Glory Beach Resort, Port Dickson on 21 ${ }^{\text {st }} 24^{\text {th }}$ February 2014.

The research is built and developed on a design which is qualitative in nature. It adopts research methodologies such as critical and content analysis, field interviews and observation for data verifications. The methodologies of critical and content analysis are used in harping data and information when the contents all materials referred to on the evolvement of the syariah courses at the Law Faculty UKM in general and the course of Syariah Evidence Law in particular are critically examined. In addition, field interviews are conducted on past and present students of Syariah Law of Evidence on past weaknesses of the said course and the extent of effectiveness of the mock trial simulation technique currently incepted into its teaching and learning process. During the field study, the methodology of observation is also adopted in assessment of the effectiveness of the said new teaching tool when the whole running of this new teaching technique and the extent of its effectiveness are critically observed and gauged.

\section{Early Development and Evolution of the Syariah Curriculum at the Faculty of Law, UKM}

Driven by the aim to produce excellent graduates in both civil and syariah laws, the Faculty has been consistent and vigorous in enhancing the syariah curriculum. This was to ensure the graduates remain competitive and able to meet the needs and demands of the industries. 
The syariah law courses began with the Faculty establishment in 1984. The courses offered at that point of time were Introduction to Islamic Law and Islamic Civilisation and Nationhood which were introduced to the first year students, Islamic Jurisprudence- Family, Succession and Commercial Transaction which was introduced to the second year students, and Islamic Jurisprudence- Crime and the Administration of Law which was then introduced to the third year students. Meanwhile, no Syariah law courses were on offer for the final year students (A. Halim, 1996; Rohimi, 1994). The list of syariah courses offered is outlined clearly in the following table:

\begin{tabular}{|l|l|}
\hline Year of Study & Syariah course at Faculty of Law, UKM \\
\hline Year 1 & Introduction to Islamic Law, Islamic Civilisation and Nationhood \\
\hline Year 2 & Islamic Jurisprudence- Family, Succession and Commercial Transaction \\
\hline Year 3 & Islamic Jurisprudence- Crime and the Administration of Law \\
\hline Year 4 & No Syariah law courses on offer \\
\hline
\end{tabular}

In 1993/94 academic session, the Syariah courses were revamped for content and focus enhancement. More specific and detailed courses began to be offered. Syariah courses offered during that academic year were more detailed in terms of its contents and focus. For the first year students, UK 1113-Introduction to Islamic Law I was introduced in the first semester while UK 1123-Introduction to Islamic Law II was introduced in the second semester. Meanwhile, for the second year students, UK 2113-Islamic Jurisprudence- Family, Succession and Commercial Transaction I was introduced in the first semester while in the second semester, the course of UK 2123 Islamic Jurisprudence- Family, Succession and Commercial Transaction II was introduced. In addition, the third year students were exposed to the course of UK 3093Islamic Jurisprudence- Crime and the Administration of Law I (the code was changed to UK 3113 in the 1994/95 session) in the first semester while in the second semester, the third year students had UK 3103 Islamic Jurisprudence- Crime and the Administration of Law II as their syariah paper (the code was later changed to UK 3123 in the 1994/95 session). Meanwhile, there was no compulsory syariah course on offer for the final year students. However, UK 4593 Principles of Islamic Jurisprudence I and Principles of Islamic Jurisprudence II were offered as one of the electives for semester 1 and 2 (Rohimi, 1994; A. Halim, 1996). The list of syariah courses offered are outlined clearly in the following table:

\begin{tabular}{|r|l|}
\hline \multicolumn{1}{|c|}{ Year of Study } & Shariah courses at the Faculty of Law UKM \\
\hline Year 1, Semester 1 & UK 1113 Introduction to Islamic Law I \\
\hline Semester 2 & UK 1123 Introduction to Islamic Law II \\
\hline Year 2, Semester 1 & UK 2113 Islamic Jurisprudence- Family, Succession and Commercial Transaction I \\
\hline Semester 2 & UK 2123 Islamic Jurisprudence- Family, Succession and Commercial Transaction II \\
\hline Year 3, Semester 1 1 & $\begin{array}{l}\text { UK 3093 Islamic Jurisprudence- Crime and the Administration of Law I } \\
\text { (Code changed to UK 3113 in 1994/95 session) }\end{array}$ \\
\hline Semester 2 2 & $\begin{array}{l}\text { UK } 3103 \text { Islamic Jurisprudence- Crime and the Administration of Law (Code changed to UK } \\
3123 \text { in 1994/95 session) }\end{array}$ \\
\hline Year 4, Semester 1 1 & $\begin{array}{l}\text { No compulsory course on offer. } \\
\text { UK 4593 Principles of Islamic Jurisprudence I- Elective course }\end{array}$ \\
\hline Semester 2 2 & $\begin{array}{l}\text { No compulsory course on offer. } \\
\text { UK 4603 Principles of Islamic Jurisprudence II- Elective course }\end{array}$ \\
\hline
\end{tabular}

\section{Evolution of Syariah Curriculum at the Faculty of Law during the Era of Development, Specifications and Introduction of More Specific Courses}

For academic session 1997/98, a significant initiative was taken to enhance the syariah curriculum at the Faculty. It involved an offer of a new course of more practical orientation, and division of an existing course into 2 compulsory courses more specificity content-wise.

For semester 1 and semester 2 of the academic session, the courses of UK 4112 Law of Evidence and Procedures of Syariah Court I and UK 4122 Law of Evidence and Procedures of Syariah Court II began to be offered as compulsory courses for the final year students. The courses were aimed to expose students to aspects of evidence and procedures of civil and criminal trial at syariah court. The courses were in line with the aim to produce graduates who are also skilful in syariah law (A. Haji, 2013; Shariff, 2015).

Meanwhile, another important revamp was on UK 2113 Islamic Jurisprudence- Family, Succession and Commercial Transaction I; and UK 2123 Islamic Jurisprudence- Family, Succession and Commercial Transaction II. Both courses were then divided into 2 more specific courses. As a consequence, UK 2113 Islamic Jurisprudence- Family, 
Succession and Commercial Transaction became a compulsory course for Year 2, semester 1, while Islamic Succession was a compulsory course in Year 2 ,semester 2 (Hakimah, 2014; Ahmad, 2013).

At the same time, new courses of Muamalat I and Muamalat II were introduced as compulsory courses for Year 3, semester 1 and 2. The UK 3113 Islamic Criminal Law I and UK 3123 Islamic Criminal Law II which previously were compulsory courses for Year 3, semester 1 and 2 were given new codes. The new codes were UK 2113 Islamic Criminal Law I and UK 2123 Islamic Criminal Law II respectively, and both were compulsory courses for Year 2, semester 1 and 2 (Yusro, 2013).

The aforementioned development was a major evolution toward enhancement and consolidation of the Syariah curriculum at the Faculty. The list of these revamped syariah courses are outlined clearly in the following table:

\begin{tabular}{|l|l|}
\hline Year of Study & Syariah Courses at the Faculty of Law, UKM \\
\hline Year 1, Semester 1 & UK 1113 Introduction to Islamic Law I \\
\hline Semester 2 & UK 1123 Introduction to Islamic Law II \\
\hline Year 2, Semester 1 1 1 UK 2113 Islamic Criminal Law I \\
\\
$\begin{aligned} \text { (Previously UK 3113 a compulsory course for Year 3 sem 1) } \\
\text { UK 2133 Islamic Family Law }\end{aligned}$ \\
\hline Semester 2 2 & $\begin{array}{l}\text { UK 2123 Islamic Criminal Law II } \\
\text { (Previously UK 3123 a compulsory course for Year 3 sem 1) } \\
\text { UK 2143 Islamic Law of Succession }\end{array}$ \\
\hline Year 3, Semester 1 1 & UK 3132 Muamalat I \\
\hline Semester 2 & UK 3142 Muamalat II \\
\hline Year 4, Semester 1 & UK 4112 Law of Evidence and Procedures of Shariah Court I \\
\hline Semester 2 & UK 4122 Law of Evidence and Procedures of Shariah Court II \\
\hline
\end{tabular}

\section{Critical Development in the Syariah and Civil Practice in Malaysia}

The year of 2000 onwards saw a dawn of a more sophistication era in the civil and syariah legal practice in Malaysia. As a country which adopt a dual legal systems of both civil and syariah, Malaysia witnessed an influx of freshly graduated lawyers in the market. The civil legal practice, being the more dominant legal system of the two, started to become critical on the standard of these newbies and rightly so. The Malaysian Bar Council expressed their concerned on the downslide of the quality of new lawyers that the public universities were producing. The same sentiment was echoed by the Malaysian Judiciary and the Malaysian Attorney's Chambers (Faridah, 2014; A. Haji, 2013). This development had a domino effect on the syariah legal industry. Since the public universities, UKM included, were producing law graduates who could practice at the civil as well as syariah courts, these public law schools and the syariah legal fraternity started to scrutinize the quality of new syariah lawyers that were being produced. In tandem with the civil development, it was also felt that the standard of the syariah lawyers needed to be raised a few notches higher (A. Haji, 2013; Shariff, 2015).

\section{Revamping the Course of Syariah Law of Evidence}

The consequential effect was that several efforts were made to revamp both the civil as well as the syariah curriculums offered at the law Faculty of UKM. One of the syariah courses reviewed was the course of Syariah Law of Evidence. Over the time, the said course was reviewed several times in ensuring its relevancy to the Malaysian syariah legal industry (Ahmad, 2013). The most recent review was conducted in the 2013/2014 session. The most recent revamp was to ensure that the said course exposes the law students to both the theoretical as well as the practical elements. A revamp of the curriculum had seen practical mock trial been embedded in the course. The mock trial trains students on correct techniques of submitting evidence in civil and syariah criminal trials. Mock trial simulation exercise used in teaching law of evidence is both an in-vitro and vitro practical experience, and it is extremely important to the students. It simulates practical skills of evidence submission in trials. Mock trial teaches students of crucial roles of proper evidence in syariah courts trials (Shariff, 2015).

A study was conducted on the final year students' responses and feedbacks on the incorporation of mock trial simulation exercises into the curriculum. A number of 83 final year students from the 2013/2014 session were interviewed before and after they went through the simulation experience. From this number, 45 students (54.2\%) verified that the whole experience had definitely helped them to understand both the theoretical as well as the practical parts of syariah law of evidence. Meanwhile 30 respondents (36.1\%) testified that they were unsure of whether they had benefitted from the mock trial experience or not. Last but not least, a number of 8 students (9.7\%) said that the whole experience did not 
help them at all. The above result showed that the incorporation of mock trial simulation exercises enjoyed a considerable success but there was definitely room for further improvements (Ahmad, 2013; Hashim, 2015).

\section{Teaching and Learning of Syariah Law of Evidence at Law Faculty, UKM: Problem Statement and Findings}

There were shortcomings in the course content of the course of Syariah Law of Evidence between 1997-2013. During these 6 years, adequate emphasis had not been given on practical matters although the theoretical aspects had been formulated comprehensively. In this aspect, there was a gap in teaching between theories and practices. As no specific mode of teaching was adopted to expose the students to the practical art of evidence submission during syariah civil and criminal trials (Ahmad, 2013).

Even when mock trial simulation was incorporated as a mode of teaching in 2013 , the result from a field study conducted on the students suggested that there were some kinks in its implementation. This has prompted the teaching team to scrutinize the implementation of the said simulation, looking for possible weaknesses in its implementation while looking at possible ways of ironing out problems. In the process, the team not only scrutinized suggestions given by the respondents, but also look at feedbacks and suggestions given by the syariah legal fraternity. Among the glaring weaknesses of the said implementation was the lack of impromptu elements in the exercise and also insufficient length of trial (Shariff, 2015; Ahmad, 2013).

\section{Recommendations}

Students need practical experience such as mock trial simulation exercises. This shall provide practical skills of evidence submission in syariah civil and criminal trials. In achieving this aim, the curriculum of Syariah Law of Evidence was revamped in 2013 to include mock trial simulation as an important teaching tool. The mock trial trains students on correct methods and techniques in submitting evidence in civil and syariah criminal trials (Ahmad, 2013).

After the incorporation of such simulation technique, there were some weaknesses identified in its implementation, namely the lack of impromptu elements in the exercise and also insufficient length of trial. The teaching team had responded to these two problems swiftly. Thus, in the next 2014/2015 session, several adjustments and modifications were made to the simulation programme. In order to ensure elements of surprise in the mock trial process, students' preparation time was shortened from 5 weeks to 2 weeks. This guaranteed that students were only given 2 weeks to prepare according to the assigned mock problem. In addition, they were not allowed to have a direct discussion with their respective opponents unless in presence of teachers or trainers (Shariff, 2015). Meanwhile, in response to the complaint on insufficient timing, the team had decided to adopt a one day, one trial approach, as opposed to the previous two trials per day method. Such modification would ensure that each trial will have the luxury of 8-10 hours to be completed as opposed to the previous 4-5 hours' time frame (Shariff, 2015).

\section{Conclusion}

The gap between theories and practices in teaching Syariah Law of Evidence have been identified and addressed ever since. A revamp of the curriculum has exclusively and effectively incorporated mock trial simulation exercises as its main teaching tool. As pointed out earlier on in this paper, the research has unearth the significance of adopting the new mock trial simulation technique as a teaching tool of the said course. The said simulation exercises have exposed students to the proper technique of tendering and submitting evidence in syariah civil and criminal trial. Given the present growth and development in syariah legal practice, the skills of evidence tendering and submission are indeed crucial.

The Syariah Law of Evidence course has, thus, provided a balance emphasis on theories and practice. The course has exposed and trained students on the correct procedures for submission of evidence correctly in both syariah civil and criminal trials. Through mock trial, the course of Islamic Law of Evidence shall be able to produce graduates capable of practicing effectively in syariah court trials in their future legal careers.

\section{References}

A. Haji B. (2013). Bachelor of Law Programme at Faculty of Law UKM: A curriculum Review. Retreat Programme. Cheringin Hill Resort, Janda Baik, Pahang, 2013.

A. Halim Muhammad. (1996). Syariah Courses at the Law Faculty UKM: An Overview of Its Significance and Development. Paper Presented at Faculty of Law Retreat Programme. Riviera Resort, Melaka, 1996. 
Ahmad A. Mohd Shariff. (2013). Teaching and Learning of Syariah Evidence Course: A UKM's Law School Experience. International Conference on Teaching and Learning. Universiti Sains Islam Malaysia (USIM), Nilai, Negeri Sembilan. October 2013.

A. Hakimah A. Halim. (2014). Review of LL.B Curriculum at UKM's Faculty of Law: A Report on Syariah Courses Content Review. Workshop on Law Curriculum Review. Port Dickson, Negeri Sembilan. May 2014.

Faridah A. Jalil. (2014). Law Curriculum Review by Faculty of Law UKM: Proposed Amendments and Revamps. Workshop on Undergraduates Teaching and Learning. Glory Beach Resort, Port Dickson. 21st-24th February 2014.

F. Yusro Hashim. (2013). Teaching and Learning Islamic Family Law: The Experience of Faculty of Law UKM. International Conference on Teaching and Learning. Universiti Sains Islam Malaysia (USIM), Nilai, Negeri Sembilan. October 2013.

Haji Hashim, F. Y. (2015). Convention on Innovation in Teaching and Learning Islamic Family Law: The Experience of Faculty of Law UKM. Convention on Innovation in Teaching and Learning. Universiti Kebangsaan Malaysia, Bangi, Selangor. May 2015

Mohd Shariff, A. A. (2015). Convention on Innovation in Teaching and Learning Islamic Family Law: The Experience of Faculty of Law UKM. Convention on Innovation in Teaching and Learning. Universiti Kebangsaan Malaysia, Bangi, Selangor. May 2015

Rohimi Shapie. (1994). Law Curriculum at UKM: An Overview and Projection. Paper Presented at Faculty of Law Retreat Programme. Bayu Beach Resort, Negeri Sembilan. October 1994. 